\title{
Testing the validity of free cash flow hypothesis: Evidence from Nigeria
}

\author{
Nnenna Georgina Nwonye ${ }^{1}$, Sebastine Ugochukwu Ugwuegbe ${ }^{2 *}$ \\ Department of Banking and Finance, University of Nigeria, Enugu Campus ${ }^{1}$ \\ Department of Banking and Finance, Caritas University, Enugu Nigeria2* \\ nnenna.nwonye@unn.edu.ng ${ }^{1}$, uugwu22@gmail.com²*
}



Article History

Received on 10 February 2020

Revised on 15 February 2020

Accepted on 28 February 2020

\begin{abstract}
Purpose: This study empirically tests the validity of the free cash flow hypothesis among firms quoted on the Nigerian Stock Exchange (NSE) from 2007 to 2017.
\end{abstract}

Research methodology: The study employed a dynamic panel system Generalized Method of Moments (GMM) in analyzing the data generated.

Results: the result failed to provide empirical evidence in support of the Jensen free cash flow hypothesis in Nigeria. The equally showed that a high concentration of shareholding in the hand of a few individual increases the amount of dividend paid out to shareholders. The result is however robust using different methods.

Limitations: We focused only on testing the validity of the free cash flow hypothesis proposed by Jensen (1986).

Contribution: The study provided empirical evidence that invalidates the propositions of the free cash flow hypothesis among publicly quoted firms in Nigeria. The result is robust using different estimation techniques.

Keywords: Free cash flow hypothesis; Dividend payout

How to cite: Nwonye, N.G., 1, Ugwuegbe, S. U. (2020). Testing the validity of free cash flow hypothesis: Evidence from Nigeria. International Journal of Financial Accounting and Management, $1(3), 155-165$.

\section{Introduction}

The concept of free cash flow has gained increasing attention in corporate finance literature following the work of Jensen (1986) which brought the Free Cash Flow (FCF) hypothesis to the limelight. The Jensen free cash flow hypothesis presupposes that management of firms with increasing FCF's tends to invest in a project with negative Net Present Value (NPV) to enrich themselves at the expense of the owners of the firm. According to Kadioglu and Yilmaz (2017) managers of firms employ free cash flow as a tool to promote their selfish interests at the detriment of the shareholders. And so, as the free cash flow increases in the firm, the agency cost increases proportionately due to conflict of interest between managers and shareholders (Zhang et al, 2016). Yeo (2018) however, noted that firm managers have incentive to invest instead of distribution to the shareholders even when the investment produces a negative NPV. We focused only on testing the validity of the free cash flow hypothesis proposed by Jensen (1986).

It is based on the forgoing that the free cash flow hypothesis asserts that managers with increased FCF will prefer to invest in negative NPV projects rather than distributing the FCF as dividends to the shareholders. Managers with FCF will deliberately avoid debt financing and dividend payout as these options will reduce the FCF under their control and move will increase the agency problem faced by the firm. Several studies have been conducted in different economies of the world examining the effect of free cash flow on dividend payout policy of publicly quoted firms, but different conclusions 
reached. DeAngelo and DeAngelo (2000), Kadioglu and Yilmaz (2017), La Porta, Loper-de-Silanes, Shleifer and Vishny (2000) provided empirical evidence supporting the free cash flow hypothesis in their various studies. On the other hand Byrd (2010), Khan, Kaleem, and Nazir (2012), and Zhang (2009) concluded in their studies that debt financing reduces free cash flow in the hand of the management as they are under obligation to settle their outstanding indebtedness. While Titman, Wei, and Xie (2004) and Fairfield, Whisenant, and Yohn (2003) reported that firms with free cash flow make extreme investments hence leading to the poor performance of the firm.

Despite what may seem like an avalanche of research work in this subject area in other jurisdiction of the world, no study to the best of our knowledge has tested the validity of free cash flow hypothesis in Nigeria or investigated the effect of free cash flow on dividend payout of firms quoted on the Nigerian stock exchange. We could not also find any study that examined the interaction effect of free cash flow with ownership concentration and board ownership on dividend payout of firms in Nigeria.

This study, therefore, examines the validity of the free cash flow hypothesis among firms publicly quoted on the Nigerian stock exchange using a sample of 65 firms for the period of 2007 to 2017. A panel dynamic Generalized Method of Moments (GMM) was used to establish the effect of free cash flow on dividend payout of the sampled firms in Nigeria for the period under investigation. The rest of the study is structured as follows: section two of the study provides a review of relevant literature, section three presents the data and methodology for the study while, section four presents the result and the interpretation of the analysis. Finally, we present the conclusion and policy recommendations in section five of the study.

\section{Literature review}

\subsection{Theoretical review}

\subsubsection{Free cash flow hypothesis}

The free cash flow hypothesis, according to Jensen \& Meckling (1976) posits that managers tend not to behave in a way consistent with the profit maximization objective of the firm. They noted that Managers most often use increased free cash flow to pursue objectives that have little or no effect on profit growth. In line with the free cash flow postulations, the agency cost explanation introduced by Jensen, Clifford \& Smith (1995), suggests that monitoring difficulty creates the potential for management to spend internally generated cash flow on projects that are beneficial from a management perspective but costly from a shareholder perspective. It, therefore, suggests that investments in profitable projects decrease the amount of free cash flow available for them to pursue their opportunistic consumption and suboptimal investments.

Donaldson (1990), argues that managers of firms with free cash flows (cash flows above profitable investment opportunities) tend to waste cash by taking excessive perquisites or by making unprofitable investments. Similarly, Managers who control free cash flows are more likely to invest in projects that will merely increase the size of the firm (or pay themselves excessive perks), instead of paying dividends to the owners of the firm or repurchase outstanding shares to increase the market value of the share. A contestable inference drawn by the agency hypothesis is that firms that possess free cash flows are more probable to grow over the optimal point of shareholder wealth maximization. The firm's Shareholder tends to benefit from the decision of the management that helps in preventing these wasteful expenditures. One of the ways to prevent such waste is through Share repurchases, which use up the excess cash flows available within the firm (Jensen \& Smith, 1995).

Similarly, the reaction of the capital market to a drop in dividend payout is a sharp decline in the stock price of the firm's stock this, however, is consistent with the agency costs of free cash flow. Meanwhile, when Debt is created, without retaining the proceeds arising from the issue, it enables managers of a firm to effectively keep their promise to pay out future cash flows. And so, one key instrument that provides an effective substitute for dividends is debt, although something is not generally recognized in the corporate finance literature. The issuance of debt as a substitute for stock, bond managers to their promise to pay out future cash flows in a manner that cannot be accomplished 
by simple dividend increases. This, however, empowers the debt holders with the right to initiate bankruptcy proceedings against the firm in the court of law if they do not keep their promise to make the interest and principal payments as when due to the debt holders (Jensen \& Michael, 1976).

\subsection{Empirical review}

Nguyen et al (2014) in their study tested the free cash flow theory and its effect on dividend policy of firms quoted on the Vietnams Stock Exchange from 2008 to 2012 and their result showed that the firm's dividend policy is consistent with the theory of free cash flow. This, however, implies that the company that pays a dividend higher than the industry average of $47.36 \%$ has the largest free cash flow. They further suggest that the firms that pay a dividend or higher dividend are mainly small firms which the authors noted that they do so to prevent the stock price from declining. This result led the authors to question the rationale for dividend payment by smaller firms, whether they just pay a dividend to meet the needs of the investors even if there are investment opportunities that can generate a positive Net Present Value for the firm.

Wang (2010) investigated the extent to which free cash flow is associated with agency cost and how free cash flow and agency cost influence firm performance in Taiwan. Employing data from Taiwan publicly quoted companies the result showed that free cash flow has a significant impact on agency cost with two contrary effects. On one hand, he opined that free cash flow could incur agency cost due to perquisite consumption and shirking behavior; on the other hand, the generation of free cash flow, resulting from internal operating efficiency, could lead to better firm performance. Conversely, the result provides evidence of a positive and significant relationship between free cash flow and firm performance measures, demonstrating a lack of evidence supporting the free cash flow hypothesis.

Cai (2013) is a study that theoretically and empirically examined the relationship between corporate governance and firm-level over-investment of free cash flow, employing a cross-sectional paired sample of 1411 firms, annual observation of listed companies in Shanghai and Shenzhen stock exchange in China covering the period of 2003 up to 2010. The result showed that there is a significant positive association between over-investment and free cash flow.

Hejazi and Moshtaghin (2014) in their study examined the impact of agency cost of free cash flow on the dividend policy and leverage firms in Iran. The study employed data generated from 101 companies listed on the Tehran Stock Exchange from 2007 to 2012. They adopted the multivariate linear regression model by using panel fixed effect approach in the analysis of the data generated. Their result indicates that there is a positive and significant effect that the agency cost of free cash flow has on the dividend and leverage policy of the firms under study. Furthermore, firm size and profitability were shown to exert a positive and significant effect on the dividend policy of the firms quoted on the Tehran stock exchange. Kadioglu and Yilmaz (2017) investigated the validity of the free cash flow hypothesis among firms traded on Borsa Istanbul, employing a panel dataset of 1267 observations from 227 companies from 2008 to 2014. Their result provided empirical evidence supporting the free cash flow hypothesis.

Yeo (2018) examined the role of free cash flow in making investment and dividend decisions in shipping industries, employing generalized least square regression, and the result revealed that free cash flow leads to an increase in investment and reduction in dividends among a sample of 137 shipping firms from 35 countries. Although there is series of studies in Nigeria that examined the relationship between dividend policy and other variables like firm performance, share price, life-cycle theory, cash flow, and agency conflict among which are, Adelegan (2003), Tijjani \& Sani (2016), Eniola \& Akinselure (2016), Ogundipe et al (2012), Nwidobie (2013), Bingilar \& Oyadonghan (2014), Inyiama \& Nwankwo (2016), Okafor et al (2011). We could not find any study in Nigeria that directly tested the validity of the free cash flow hypothesis among firms trading in the Nigerian stock exchange.

The following hypothesis were formulated and tested.

H1: increase in free cash flow negatively affects dividend pay-out of firms in Nigeria. 
H2: changes in ownership structure do not have any effect on dividend pay-out of firms in Nigeria. H3: the interaction of free cash flow and ownership structure has no effect on dividend pay-out of firms in Nigeria.

\section{Research methodology}

The sample size for this study comprises of 30 dividend firms quoted on the Nigerian Stock Exchange. The names of the sampled firms are presented in Appendix 1. The sampling technique employed in this study is purposive sampling technique. The choice of this technique is to provide opportunities for the researcher to isolate and control for some limitations by removing some items from the population. According to Awoyemi and Bagga (2016) out of 212 quoted companies in NSE, only 124 pay divided representing 58\% of all the firms listed on the NSE. Based on the consistency of dividend payment within the last five (5) years, they reported that companies that maintain $100 \%$ dividend payment consistency represents $18 \%$ of dividend-paying firms and are mostly large firms. Similarly, $6 \%$ of dividend-paying firms maintain a dividend payment consistency of about $71-80 \%$ while $35 \%$ of the firms maintain consistency of about $50-70 \%$. The remaining $41 \%$ maintain a dividend payment consistency of less than 50\%. Following the report of Awoyemi and Bagga (2016), we arrived at a sample size of 30 dividend-paying firms which maintained 80-100\% dividend payment consistency within the period under investigation. These companies are presented below. The variables of choice comprises of dividend payout which is the dependent variable, free cash flow, total assets, board ownership, and ownership concentration which are independent variables. The study made use of the undistributed cash flow method to determine the free cash flow. The approach is similar to the one used by Kadioglu and Yilmaz (2017), Hong, Shuting, and Meng (2012), and AlZararee and Al-Azzawi (2014). The dependent variable (dividend payout) and the free cash flow were normalized using total assets although some studies normalized free cash flow using sale value. The model included natural logarithm of total assets as a control variable while the interaction of free cash flow and board ownership together with the interaction of free cash flow and ownership concentration where all included in the model to determine if the free cash flow hypothesis holds or otherwise given the ownership structure of the firm.

\subsection{Model specification}

The signalling effect theory of dividend states that increase dividend pay-out is a signal that the management of the firm is trading favourably with the investors' fund. In other words, it suggests that an increase in dividend pay-out by a company is an indication of a positive prospect. Most often than none management of the firm uses dividend signalling as an indication of good investment potential. Meanwhile, the value of a firm's dividend for the current year often tends to reflect or to a greater extent depend on the previous years' value. Implying that, the lagged values of dividend pay-out affect the current years' value. To capture this effect, a dynamic panel data model with the lagged value of dividend will have to be included as an independent variable will be most appropriate. We, therefore, adopted and modified the GMM model developed by Arellano and Bover (1995) and Bllundel and Bond (1998) to suit the current study. And so, to achieve the objectives of this study, we specify five (5) different models to address the five hypotheses stated in this work. The level form of the model, as well as the first differenced model as proposed by Arellano and Bover (1995), are as follows:

$$
\begin{aligned}
& \sum D I V_{i, t}=\sum \varphi D I V_{i, t-1}+\sum \beta F C F_{i, t}+\sum \varnothing O W C_{i, t}+\sum \partial F C F * O W C_{i, t}+\sum \delta S I Z E_{i, t}+\pi_{i} \\
& +\varepsilon_{i, t} \ldots \ldots \ldots \ldots \ldots \ldots(1) \\
& \sum \Delta d i v_{i, t}=\sum_{+\varepsilon_{i, t} \ldots \ldots \ldots \ldots(2)} \varphi \Delta d i v_{i, t-1}+\sum_{(2)} \beta \Delta f c f_{i, t}+\sum \emptyset \Delta o w c_{i, t}+\sum \partial \Delta f c f * o w c_{i, t}+\sum \delta \Delta s i z e_{i, t} \\
& i=1 \ldots \ldots N ; t=1 \ldots \ldots . T
\end{aligned}
$$


Where $\Delta$ is the difference operators, $\sum$ is the summation sign, $\beta$ is the coefficient of free cash flow, $\varphi$ is the coefficient of lagged dividend payout, $\varnothing$ is the coefficient of ownership concentration, $\partial$ is the coefficient of the interaction term, $\delta$ is the coefficient of firm Size, $\varepsilon$ is the error term. $D I V_{i, t}$ is the Dividend Payout as a ratio of total assets, $D I V_{i, t-1}$ is the Dividend Payout as a ratio of total assets for the previous period, $F C F_{i, t}$ is the Free Cash Flow to equity as a ratio of total assets, $\mathrm{OWC}_{\mathrm{i}, \mathrm{t}}$ is the Ownership Concentration, $\mathrm{FCF}^{*} \mathrm{OWC}_{\mathrm{i}, \mathrm{t}}$ is the Interaction between free cash flow and ownership concentration $S_{I Z E_{i, t}}$ is the Natural Logarithm of the firm's Total Assets

\subsection{Techniques of data analysis}

This study examined the effect of free cash flow on the dividend policy of publicly quoted firms in Nigeria. We began the estimation procedure by estimating a linear dynamic panel-data (DPD) model to capture the effect of lagged dividend pay-out on the current dividend pay-out. DPD models contain unobserved panel-level effects that are correlated with the lagged dependent variable, and this renders standard estimators inconsistent. The Arellano and Bond (1991) difference GMM estimator provides consistent estimates for such models. This estimator differences the data first and then uses lagged values of the endogenous variables as instruments. However, as pointed out by Arellano and Bover (1995), lagged levels are often poor instruments for first differences. Blundell and Bond (1998) proposed a more efficient estimator, the system GMM, which mitigates the problem of the weak instrument by using additional moment conditions. The system GMM uses more instruments than the difference GMM, and therefore one might expect the system estimator to be more biased than the difference estimator. However, Hayakawa (2007) shows that the bias is smaller for the system than the difference GMM. Specifically, the bias of the system GMM estimator is smaller because it is a weighted sum of the biases of the difference and the level estimator, and that these biases move in opposite directions. We, therefore, use the more efficient and less biased system GMM estimator for our regressions. We now point out some potential caveats of the system GMM estimator and discuss how these problems are addressed. The first issue relates to the validity of the instruments.

Second, the procedure assumes that there is no second-order autocorrelation in the idiosyncratic errors. Another pertinent issue is that the test for autocorrelation and the test for the validity of the instruments lose power when the number of instruments, $I$, is large relative to the cross-section sample size (in our case, the number of firms), $n$. specifically, when the instrument ratio, $\mathrm{r}$, defined as $r=i=$ less than 1, the assumptions underlying the two procedures are likely to be violated (Roodman, 2006). Furthermore, a low $r$ raises the susceptibility of the estimates to a Type 1 error-i.e., producing significant results even though there is no underlying association between the variables involved. The easiest solution to this problem is to restrict the number of lags of the dependent variable used for instrumentation to the point where $r \geq 1$ (Roodman, 2006).

To address these potential problems, we test for autocorrelation and the validity of instruments for each regression. Specifically, for each regression, we report the p-values for the test for second-order autocorrelation as well as the Hansen-J test for over-identifying restrictions. We report the results for the regressions, and the p-values to indicate whether the assumption of no second-order autocorrelation is satisfied in each of the regressions. Furthermore, the instruments are valid in all the estimated regressions. Thus, the two assumptions are satisfied in our specifications. Furthermore, in all the regressions, $r \geq 1$, and therefore we do not restrict the number of lags of the dependent variable used for instrumentation. We end the section by providing some details about our estimation strategy. First, we use the two-step GMM estimator, which is asymptotically efficient and robust to all kinds of heteroskedasticity. Second, the independent variables are treated as strictly exogenous in all the regressions. Besides, our regressions utilize only internal instruments - we do not include additional (external) instruments. Note that the system estimator uses the first difference of all the exogenous variables as standard instruments, and the lags of the endogenous variables to generate the GMM-type instruments described in Arellano and Bond (1991). Furthermore, the system estimations include lagged differences of the endogenous variables as instruments for the level equation. 


\subsection{Model diagnostics}

One of the problems associated with Arellano and Bond (1991) GMM estimator is the overidentification of instruments. Since the estimator employs different lags instruments in other to eliminate the firm-specific effect, hence given rise to proliferation of instrument. The effect of instrument proliferation in the model is that too many instruments can over-fit endogenous variables, thereby failing to remove the endogenous components of the variable and as well lead to a biased coefficient estimate towards those from un-instrumented estimators. Meanwhile, to solve this problem, Arellano and Bond (1991) recommended restrictions in the model through the inclusion of collapse command in the GMM estimator. And so, to test form the validity of the restrictions in the model, the study employs Hansen and Sargan test of over-identification. Sargan-Hansen tests are the test of over-identifying restrictions, which is based on the null hypothesis that the over-identifying restrictions are valid. To proceed with the GMM dynamic panel data model, we must fail to reject the null hypothesis in both tests.

Similarly, the choice of GMM in the first place over the Ordinary Least Square (OLS) estimator is due largely to the presence of autocorrelation in the model. This arises due to the inclusion of the lagged value of the dependent variable as an explanatory variable. And so, to justify the use of GMM there must be autocorrelation of order one $(\mathrm{AR}(1))$ but not more than order one if the result of the dynamic GMM estimator is to be free from bias. The result of the AR(1) test must indicate the rejection of the null hypothesis which states there is no autocorrelation in the model and accept the alternative hypothesis of autocorrelation in the model. It is also important to note that the null hypothesis for $\mathrm{AR}(2)$ must not be rejected.

\section{Results and discussions}

The result of the system GMM as presented in table 4.1 below indicates that the coefficient of free cash flow is 0.0393 suggesting that free cash flow has a positive impact on dividend pay-out of publicly quoted firms in Nigeria. The coefficient of free cash flow as shown in the table is statistically significant at a 5\% level of significance. This result suggests that a percentage increase in free cash flow will lead to about 0.04 per cent increase in dividend pay-out of quoted firms in Nigeria on average ceteris paribus. This finding fails to provide evidence to support the Jensen (1986), free cash flow hypothesis, which argued that managers of firms tend to invest in a project with negative Net Present Value (NPV) as the free cash flow within their control increases instead of distributing them as dividend to the shareholders. The assertion that increases in free cash flow leads to unnecessary administrative waste and inefficiency resulting in a decrease in dividend pay-out could not be substantiated in this study.

Table 4.1 The result of dynamic panel GMM

\begin{tabular}{|l|l|l|l|l|}
\hline $\begin{array}{l}\text { VARIABLESVARI } \\
\text { ABLES }\end{array}$ & Syst-GMM1 & Syst-GMM2 & Diff-GMM1 & Diff-GMM2 \\
\hline L.DIV & 0.0515 & 0.0514 & 0.0738 & 0.0744 \\
\hline ASSETS & $(0.0995)$ & $(0.0994)$ & $(0.121)$ & $(0.121)$ \\
\hline & 0.00895 & 0.00907 & $0.286^{* *}$ & $0.287^{* *}$ \\
\hline FCFE & $(0.0201)$ & $(0.0199)$ & $(0.135)$ & $(0.136)$ \\
\hline & $0.0393^{* *}$ & & $0.048^{* *}$ & \\
\hline OWC & $(0.0198)$ & & $(0.0231)$ & \\
\hline
\end{tabular}




\begin{tabular}{|l|l|l|l|l|}
\hline & $(0.0121)$ & & $(0.0132)$ & \\
\hline FCFE_OWC & & 0.0460 & & 0.0450 \\
\hline Observations & 650 & $(0.0316)$ & & $(0.0442)$ \\
\hline Number of crossed & 65 & 650 & 570 & 570 \\
\hline firm effect & YES & 65 & 65 & 65 \\
\hline year effect & NO & NES & YES & YES \\
\hline
\end{tabular}

Robust standard errors in parentheses $* * * \mathrm{p}<0.01, * * \mathrm{p}<0.05, * \mathrm{p}<0.1$

$\operatorname{div}=$ dividend pay-out as a ratio of total assets

$\mathrm{fcf}=$ free cash flow to equity as a ratio of total assets

at $=$ natural logarithm of total assets

owc $=$ bulk ownership as a ratio of total outstanding shares

bown $=$ board interest as a ratio of total outstanding shares

Our findings corroborate the result of Ojode (2014) who noted that firms with high free cash flow are likely to attract more investors who seek a return on their investment by way of dividend. This is so because most investors attach significant value on cash dividend. The result also evidences the use of free cash flow by management to mitigate agency conflict as investors are paid cash dividend as free cash flow increases. Similarly, our findings indicate that possession of free cash flow does not increase agency costs as noted by Jensen (1986). Suggesting that, since the management of the firm tends to distribute the free cash flow available to them as dividends to the shareholders; the investors will not need to increase the cost of monitoring on the management that controls free cash flow. This finding is also in line with the result of Vakilifard and Shahmoradi (2014), who reported a strong relationship between free cash flow and return on equity of firms quoted in Iran stock exchange.

The result further shows that when free cash flow interacts with ownership concentration, the effect on dividend pay-out remains positive indicating that the free cash flow hypothesis is not valid among firms quoted in the Nigerian stock exchange whether the share ownership is concentrated or not. Columns 3 and 4 present the result of differenced GMM which was performed as a robustness test. It also failed to provide empirical evidence to support the propositions of the free cash flow hypothesis, confirming the robustness of the result of the system GMM.

\subsection{Result of the diagnostic test}

To ascertain whether or not the data are consistent with the assumptions of the Blundell and Bond (1998), Arellano and Bover (1995) estimator, we examined some of the commonly used diagnostic tests. In particular, the Sargan and Hansen tests statistic which examines the over-identification restrictions were reported. The two tests essentially examines whether the instruments are uncorrelated with the error terms in the estimated equation. The test is based on the null hypothesis that the instruments as a group are exogenous. There is a need to find an exogenous instrument in other to validate the System-GMM estimates.

Table 4.2 Result of the diagnostic test

\begin{tabular}{|l|l|l|l|l|}
\hline & Syst-GMM1 & Syst-GMM2 & Diff-GMM1 & Diff-GMM2 \\
\hline Hansen_test & 4.116 & 4.111 & 4.190 & 4.108 \\
\hline Hansen Prob & 0.249 & 0.250 & 0.381 & 0.392 \\
\hline
\end{tabular}




\begin{tabular}{|l|l|l|l|l|}
\hline Sargan_test & 6.018 & 6.043 & 3.370 & 3.374 \\
\hline Sargan Prob & 0.111 & 0.110 & 0.498 & 0.497 \\
\hline AR(1)_test & -2.297 & -2.299 & -2.112 & -2.113 \\
\hline AR(1)_P-value & 0.0216 & 0.0215 & 0.0346 & 0.0346 \\
\hline AR(2)_test & 1.143 & 1.147 & 0.529 & 0.530 \\
\hline AR(2)_P-value & 0.253 & 0.251 & 0.597 & 0.596 \\
\hline No. of Instruments & 7 & 7 & 7 & 7 \\
\hline
\end{tabular}

The Sargan and Hansen tests statistic together with its associated p-values is reported in the dynamic panel regression tables 4.2. The Sargan test statistics for all models show a p-value greater than 0.10, hence we are unable to reject the null hypothesis. This result is corroborated with the result of the Hansen test with all p-values greater than 0.10 leading to the failure to reject the null hypothesis. This, however, suggests that the variables are not over-identified in line with the assumption of Arellano and Bond (1991) System-GMM estimator. The second test we report is the Arellano and Bond test for autocorrelation. The null hypothesis is 'no autocorrelation' and relates to the differenced residuals. The result of AR(1) with a probability of less than 0.05 for all the estimated models indicates the rejection of the null hypothesis suggesting that there is autocorrelation at AR(1). We only report the test statistics and its associated p-values for AR(2). For all the estimated models, we are unable to reject the null hypothesis of 'no autocorrelation' for $\mathrm{AR}(2)$. It implies that there is robust evidence that all models are free from autocorrelation at the $5 \%$ level.

\section{Conclusion}

The novelty provided by this study is that it is the first study to directly test the validity of the free cash flow hypothesis among firms quoted on the Nigerian stock exchange. The study employed a sample of 65 dividend-paying firms quoted on the Nigerian stock exchange within the period of 20072017. The study provided empirical evidence that invalidates the propositions of the free cash flow hypothesis among publicly quoted firms in Nigeria. The result is robust using different estimation techniques. The interaction of free cash flow and ownership concentration affects dividend pay-out positive but statistically insignificant. This result implies that managers of a firm with free cash flow in Nigerian prefer distributing free cash flow to the shareholders as against investing it on projects with negative NPV. They chose this option because payment of the dividend is a signal that the firm is doing well which will result to increase in the market price of the firm's stock hence, increase the potential bonus accruable to the management of the firm. We, therefore, recommend that shareholders should not increase agency cost of monitoring firms with free cash flows in Nigeria as managers prefer to distribute free cash flow as a dividend instead of investing in projects with negative NPV.

\section{Limitation and study forward}

The study employed short panel data analysis techniques due to the unavailability of data for a longer period across the selected panel for the study. We equally focused on Jensen's free cash flow hypothesis across a sample of 65 countries quoted on the Nigerian stock exchange. Further studies can equally explore the validity of free cash flow on other stock exchanges in Sub-Saharan Africa.

\section{References}

Adelegan, O. J. (2003). An empirical analysis of the relationship between cash flow and dividend changes in Nigeria. $R \& D$ Management, 15 (1), 35-49.

Arellano, M. and O. Bover (1995), Another look at the instrumental variable estimation of error components models, Journal of Econometrics 68, 29-51.

Arellano, M., \& Bond, S. (1991). Some tests of specification for panel data: Monte Carlo evidence and an application to employment equations. Review of Economic Studies, 58, $277-297$. 
Al-Zararee, A.N., \& Al-Azzawi A. (2014) The impact of free cash flow on the market value of firm. Global Review of Accounting and Finance 5(2); 56-63

Awoyemi, O. and Bagga R. (2016) Five years dividend payment review for NSE quoted companies. Proshare, 1(138).

Bingilar P.F., \& Oyadonghan K.J., (2014) Cash flow and corporate performance: A case study of selected food and beverage companies in Nigeria. European Journal of Accounting, Auditing, and finance research 2(7); 77-87

Blundell, R., \& Bond, S. (1998). Initial conditions and moment restrictions in dynamic panel data models. Journal of Econometrics, 87, 115-143.

Byrd, J. (2010). Financial policies and the agency costs of free cash flow: Evidence from the oil industry. International Review of Accounting, Banking and Finance, 2(2), 23-50.

Cai, J. (2013). Does corporate governance reduce the overinvestment of free cash flow? Empirical evidence from China. Journal of Finance and Investment Analysis, 2(3), 97-126.

DeAngelo, H., \& DeAngelo, L. (2000). Controlling stockholders and the disciplinary role of corporate payout policy: A study of the time's mirror company. Journal of Financial Economics, 56, 153 207. http://dx.doi.org/ 10.1016/S0304-405X(00)00039-8.

Donaldson, L. (1990). The ethereal hand: Organizational economics \& management theory. Academy of Management Review, 15(3), 369-381.

Eniola, O.J., and Akinselure, O.P (2016). Effect of internal control on financial performance of firms in Nigeria(a study of selected manufacturing firms). IOSR Journal of Business and Management, 18(10); 80-85.

Fairfield, P. M., Whisenant, J. S., \& Yohn, T. L. (2003). Accrued earnings and growth: Implications for future profitability and market mispricing. The Accounting Review, 78, 353-371. http://dx.doi.org/10.2308/ accr.2003.78.1.353.

Hejazi R., and Moshtaghin F.S. (2014). The impact of agency costs of free cash flow on dividend policy, and leverage of firms in Iran. Journal of Novel Applied Sciences, 3(1), 14-21.

Inyiama, O. I., and Nwankwo, C. N. (2016), Effect of the theory of life cycle on size of firms in Nigeria brewery industry, Journal of Accounting \& Taxation 1(2); pp. 025-037.

Hayakawa, K. (2007). Small sample bias properties of the system GMM estimator in dynamic panel data models. Economics Letters 95, 32-38

Hong, Z., Shutting, Y., \& Meng K. (2012). The relationship between Free Cash Flow and Financial Performance Evidence from the Listed Real Estate Companies in China. 2012 International Conference on Innovation and Information Management, 36, 331-335.

Jensen, C. \& Smith, C. (1995). Stockholder, manager and creditor interests: Applications of agency theory. Recent Advances in Corporate Finance. E. I. Homewood, Illinois, Irwin: 93-131

Jensen, M. C. (1986). Agency costs of free cash flow, corporate finance, and takeovers. The American Economic Review, 76, 323-329. https:// dx.doi.org/10.2139/ssrn.99580

Jensen, M. C., \& Meckling, W. H. (1976). Theory of the firm: managerial behavior, agency costs, and ownership structure. Journal of Financial of Economics, 76, 305-360, http://doi.org/10.2139/ssrn.94043

Kadioglu E. \& Yilmaz E. A. (2017), Is the free cash flow hypothesis valid in Turkey? Borsa Istanbul Review 17(2); 111-116

Khan, A., Kaleem, A., \& Nazir, M. S. (2012). Impact of financial leverage on agency cost of free cash flow: Evidence from the manufacturing sector of Pakistan. Journal of Basic and Applied Scientific Research, 2, 6694-6700.

La Porta, R., Lopez-de-Silanes, F., Shleifer, A., \& Vishny, R. W. (2000). Agency problems and dividend policies around the World. The Journal of Finance, 55, 1-33. http://dx.doi.org/10.1111/0022-1082.00199.

Nguyen, G.D., Nguyen, B.L., \& Truong, N. (2014). The test of free cash flow theory evidence from dividend policy in Vietnam. The International Conference on Finance and Economics (pp. 415422).

Nwidobie, B. M. (2013). Agency conflict and corporate dividend policy decisions. Asian Economic and Finacial Review, 3(8), 1110-1121 
Ogundipe, O.O., Ogundipe, S.E., \& Ajao, S.K. (2012). Cash holding and firm characteristics: Evidence from Nigerian emerging market. Journal of Business, Economics, and Finance 1(2); 45-58.

Ojode. (2014). Effect of free cash flow on the profitability of firms listed on the Nairobi securities exchange. An unpublished master's degree project work of school of business Nairobi.

Okafor C. A., Mgbame C.O., \& Chijoke-Mgbame A. M. (2011). Dividend policy and stock price volatility in Nigeria. Journal of Research in National Development, 9, pp. 202-210.

Roodman, D. (2006). How to do xtabond2: An introduction to "Difference" and "System" GMM in Stata. Center for Global Development Working Paper N. 103.

Tijjani, B., \& Sani A.A. (2016). An empirical analysis of free cash flow and dividend policy in the Nigerian oil and gas sector. Research Journal of Finance and Accounting 7(12); 154-160

Titman, S., Wei, K. C. J., \& Xie, F. (2004). Capital investments and stock returns. Journal of Financial and Quantitative Analysis, 39, 677-700. http://dx.doi.org/10.1017/S0022109000003173.

Vakilifard, H. R., \& Shahmoradi, N. (2014). Investigating the effects of stable profitability and free cash flow on stock returns of companies listed in Tehran Stock Exchange. International Journal of Academic Research in Accounting, Finance and Management Sciences, 4(3), 21-27. http://doi.org/10.6007/IJARAFMS/v4-i2/977

Wang, G. Y. (2010). The impacts of free cash flows and agency costs on firm performance. Journal of Service Science and Management, 03, 408-418. http://dx.doi.org/10.4236/jssm.2010.34047

Yeo H. (2018). Role of free cash flows in making investment and dividend decisions: the case of the shipping industry. The Asian Journal of Shipping and Logistics 34(2); 113-118.

Zhang, D., Cao. H., Dickinson D.G., \& Kutan, A.M. (2016). Free cash flows and overinvestment: Further evidence from Chinese energy firms. Energy Economics, Vol. 58, pp.116-124.

Zhang, Y. (2009). Are debt and incentive compensation substitutes in controlling the free cash flow agency problem?. Financial Management, 38, 507-541. http://dx.doi.org/10.1111/j.1755053X.2009.01046.X.

\section{Appendix 1}

\begin{tabular}{|c|c|c|c|c|}
\hline $\begin{array}{l}\text { 7-Up Bottling } \\
\text { Comp. Plc. }\end{array}$ & $\begin{array}{ll}\text { Julius } & \text { Berger } \\
\text { Nig. Plc. } & \end{array}$ & $\begin{array}{ll}\text { Dangote } & \text { Sugar } \\
\text { Refinery Plc } & \end{array}$ & $\begin{array}{l}\frac{\text { First Bank of }}{\text { Nigeria Holdings }} \\
\underline{\text { Plc }}\end{array}$ & $\begin{array}{ll}\text { Guinness } & \text { Nig } \\
\underline{\text { Plc }} & \end{array}$ \\
\hline $\begin{array}{ll}\text { A.G. Leventis } \\
\text { Nigeria Plc. }\end{array}$ & $\begin{array}{l}\frac{\text { Aluminium }}{\text { Extrusion }} \text { Ind. } \\
\underline{\text { Plc. }}\end{array}$ & $\begin{array}{l}\text { Royal Exchange } \\
\text { Plc. }\end{array}$ & $\begin{array}{ll}\text { First } & \text { City } \\
\text { Monument } & \text { Bank } \\
\text { Group Plc. }\end{array}$ & $\begin{array}{l}\text { Honeywell } \\
\text { Flour Mill Plc }\end{array}$ \\
\hline Access Bank Plc. & $\underline{\text { Berger Paints Plc }}$ & $\underline{\text { Diamond Bank Plc }}$ & Fidelity Bank Plc & Presco Plc \\
\hline John Holt Plc. & $\begin{array}{l}\text { Cadbury Nigeria } \\
\text { Plc. }\end{array}$ & $\underline{\text { Conoil Plc }}$ & $\begin{array}{l}\frac{\text { Ecobank }}{\text { Transnational }} \\
\underline{\text { Incorporated }}\end{array}$ & U A C N Plc. \\
\hline $\begin{array}{l}\text { African Alliance } \\
\text { Insurance } \\
\underline{\text { Company }} \mathrm{Plc}\end{array}$ & $\underline{\text { Roads Nig Plc. }}$ & $\begin{array}{l}\underline{\text { Daar }} \\
\underline{\text { Communications }}\end{array}$ & $\begin{array}{l}\text { Evans Medical } \\
\text { Plc. }\end{array}$ & $\begin{array}{l}\text { Flour Mills Nig. } \\
\text { Plc. }\end{array}$ \\
\hline $\begin{array}{l}\text { African Paints } \\
\text { (Nigeria) Plc. }\end{array}$ & $\begin{array}{ll}\text { Nestle Nigeria } \\
\underline{\text { Plc. }}\end{array}$ & $\begin{array}{ll}\text { Dangote } & \text { Cement } \\
\underline{\text { Plc }} & \end{array}$ & $\begin{array}{l}\frac{\text { Universal }}{\text { Insurance }} \\
\underline{\text { Company } \mathrm{Plc}}\end{array}$ & Forte Oil Plc. \\
\hline
\end{tabular}




\begin{tabular}{|c|c|c|c|c|}
\hline Academy & $\begin{array}{l}\text { Associated Bus } \\
\text { Company }\end{array}$ & $\begin{array}{l}\text { Avon Crown caps } \\
\text { \& Containers }\end{array}$ & B.O.C Gases Nig & $\begin{array}{l}\text { Beta Glass } \\
\text { Company }\end{array}$ \\
\hline Chellarams & $\begin{array}{l}\text { Chemical \& } \\
\text { Allied Product }\end{array}$ & $\begin{array}{l}\text { Continental } \\
\text { Reinsurance }\end{array}$ & $\begin{array}{l}\text { Cornerstone } \\
\text { Insurance }\end{array}$ & $\begin{array}{l}\text { Custodian } \quad \& \\
\text { Allied Insurance }\end{array}$ \\
\hline $\begin{array}{l}\text { Lafarge Cement } \\
\text { Wapco Nig }\end{array}$ & $\begin{array}{l}\text { GlaxoSmithKline } \\
\text { Nig }\end{array}$ & Ikeja Hotel & $\begin{array}{l}\text { Learn Africa } \\
\text { (Longman) }\end{array}$ & $\begin{array}{l}\text { May \& Baker } \\
\text { Nig }\end{array}$ \\
\hline Mobil Nig & Nascon Allied & $\begin{array}{ll}\text { National Aviation } \\
\text { Handling }\end{array}$ & Nem Insurance & $\begin{array}{l}\text { Nigerian } \\
\text { Enamelware }\end{array}$ \\
\hline Okomu Oil Palm & Total Nigeria & Transcorp Nig & University Press & Vitafoam Nig \\
\hline Updc Property & Unilever Nig & $\begin{array}{l}\text { Tripple Gee } \quad \& \\
\text { Company }\end{array}$ & Transcorp Nig & Sterling Bank \\
\hline Cutix & Oando & $\begin{array}{l}\text { Nigerian } \\
\text { Flour Mill }\end{array}$ & $\begin{array}{l}\text { Nigerian } \\
\text { Enamelware }\end{array}$ & $\begin{array}{l}\text { Mrs (Texaco } \\
\text { Chevron) }\end{array}$ \\
\hline
\end{tabular}

